\title{
Lost opportunity: Fear of flying, airline profits, and the economy
}

\author{
Gary L. Thompson a*, Annette E. Craven ${ }^{b}$ \\ a University of the Incarnate Word, DBA student, Cibolo, TX 78108. \\ b University of the Incarnate Word, Professor of Management, H-E-B School of Business and Administration, San Antonio, TX 78209, E-mail: \\ craven@uiwtx.edu \\ "Corresponding author's email address: retired_atc_chief@yahoo.com, Geep99@outlook.com
}

\section{A R T I C L E I N F O}

Received: 03-01-2017

Accepted: 15-02-2017

Available online: 10-03-2017

\section{Keywords:}

Airline Finance; Economics;

Fear of Flying; Travel Demand.

JEL Classification:

D40; L91; L93; R41; R10.

\begin{abstract}
A B S T R A C T
The purpose of this study is to examine the relationship between fears of flying and U.S. airline load factors to determine if there is a potential impact on corporate profits and the economy. Travelers with a reluctance towards flying represent a potential lost opportunity for airline companies, a source of operating profits, and positive economic impacts. This research examines the psychological reservations towards flying, how avoidance behaviors impact demand and the projected implications. The paper suggests revising conceptual financial considerations to assess whether stakeholders in the commercial U.S. air travel industry should attempt to recoup lost passengers who avoid flying out of fear.
\end{abstract}

(C) 2017 The Authors. This is an open access article under the terms of the Creative Commons Attribution License 4.0, which allows use, distribution and reproduction in any medium, provided the original work is properly cited.

\section{Introduction}

Today, commercial air travel is a common mode of transportation with broad economic impacts. In a largely unregulated, less subsidized industry such as the U.S. airline market, companies rely on demand to generate profits and impart capital into the economy. Ever since the first paid passenger flight in 1914, airlines have faced difficulties in consistently generating demand, which influences business strategies beyond product or price differentiation (Belobaba, 1987). From those early flights, a complimentary relationship evolved where commercial aviation has a positive effect on the economy (Iatrou, 2014). Commercial airlines provide jobs, infuse capital, and increase economic growth cycle times which increases GDP (Kappler \& Sachs, 2013; Hansman \& Ishutkina, 2009). For every 100 jobs an airline generates, supporting industries generate an additional 600 jobs. For every $\$ 100$ of revenue earned by the airline industry an additional $\$ 325$ of indirect revenue is generated (Iatrou, 2014). The International Air Transport Association (2015) and the U.S. Department of Transportation (2015) estimate one percent of the aggregate global GDP is funneled into airlines by providing the consumers, technology, and infrastructure required to sustain a profitable industry.

Even considering the overall positive influence on GDP, the commercial aviation industry encounters several micro and macroeconomic obstacles that shape their profitability. Volatile fuel prices, fluctuating exchange rates and shifting consumer values make predicting operating costs and profits challenging (Belobaba, Odon \& Barnhart, 2015; Hernandez \& Wiggins, 2014). Larger air carriers must adapt to negative economic impacts by hedging fuel cost, forming alliances, merging, investing, code-sharing, or using hub and spoke operations. Lowcost air carriers become highly dependent on strict cost control measures (Armantier \& Richard, 2008). Common 
to all air carriers are the use of industry standard financial metrics to monitor and manage efficiency, cost effectiveness, and profitability (Vasigh, Fleming \& Taeker, 2008). Financially centered research on traditional demand variables of airline companies has been extensive. Likewise, a significant amount of psychological studies on aviophobia have been conducted. However, there are few, if any, discussions on the direct relationship of fear of flying to demand opportunities, profitability, and potential economic impacts. Although the U.S. airlines have welcomed positive increases in net income in recent years, the industry must be prepared to face erratic downward shifts. Figure 01 shows theses spikes and shocks over the last decade. While recent research focuses on fuel costs and geopolitical events that influence pricing and demand, the need to sustain or improve income flows necessitates recovering other lost opportunities. This paper examines, with an integrative literature review, whether fear of flying represents a significant amount of lost profit and lost economic opportunity and a comprehensive look at the variables.

Figure 1: Net income from domestic flights, Adapted from United States department of transportation, bureau of transportation statistics, 2015.

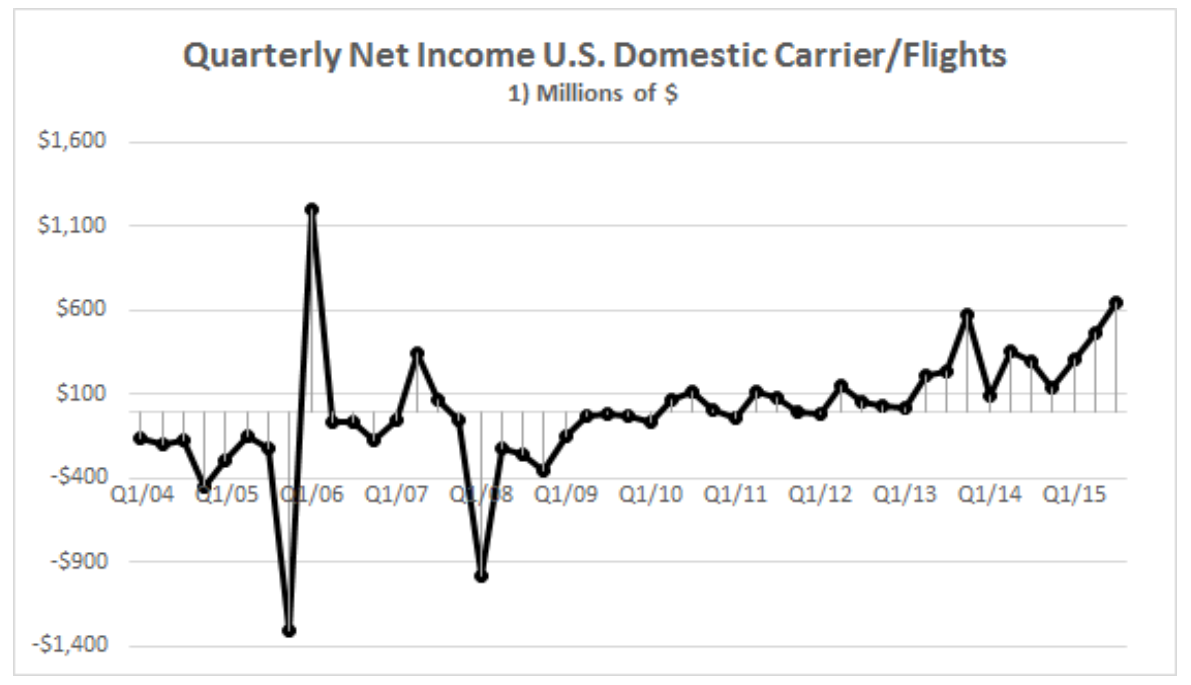

\section{Background and literature review}

To generate the specificity needed to respond to the broader research question of whether fear of flying represents a significant amount of lost profit and lost economic opportunity requires a comprehensive look at each of the variables. It is essential to understand the extent in which fear persists among travelers to determine if it has a negative influence on demand and profitability. To examine the relationship of passenger loads to demands an understanding of how profits are determined is also needed.

\subsection{Fear of flying}

The Diagnostic and Statistical Manual of Mental Disorders (4th ed., text rev.; DSM-IV-TR; American Psychiatric Association, 2000) provides detailed criteria for a phobia associated with flying known as aviophobia. This diagnosis is a variant of a particular subtype phobia limited to the act of flying. It is hard to assess all the effects of aviophobia because those inflicted with symptoms such as anxiety or panic can simply avoid flying (4th ed., text rev.; DSM-IV-TR; American Psychiatric Association, 2000). The causes and intensities of individuals who fear flying are numerous. To obtain a more holistic perspective of the impacts of fear of flying this study applies not only to those clinically diagnosed but also includes those not diagnosed who have an admitted aversion to flying associated with fear.

Fear of flying is a common psychological condition that has no socio-economic boundaries: Anyone can experience it. Crangle (2010) estimates as many as 500 million people worldwide refuse to fly, and an even greater number endure flying while professing a fear. There are two specific tools, Flight Anxiety Situations (FAS) and Flight Anxiety Modality (FAM) questionnaires, which can assess aggregate effects of fear of flying phobia (Laker, 2012). While the FAM examines fear from two perspectives, somatic and cognitive modality, and implies a relationship between the two, the FAS assessment examines fear in the chronological order it is experienced, from pre-flight to in-flight, and explores the relationships as contributing to an overall state of general anxiety (Faraci, Triscari, D'Angelo \& Ursof, 2011). Although both surveys measure outcomes differently, research supports the validity and reliability of both assessments in diagnosing aviophobia (Nousi, Van Gerwen \& Spinhoven, 2008; Van Gerwen, Diekstra, Arondeus \& Wolfger, 2004). 
Apart from people formally evaluated and diagnosed with aviophobia, an even larger segment of the population is either undiagnosed or simply has an apprehension or expressed fear of flying. Several studies indicate 50 percent of the population exhibit some apprehension to flying associated with an undiagnosed phobia (Evangelisti, 2008; Van Gerwen, Diekstra, Arondeus, \& Wolfger, 2004). We conclude from the literature that fear manifests itself in a broad range of flight avoidance from clinically diagnosed aviophobiacs who likely refuse to fly, to an undiagnosed segment of potential passengers who resist flying. To determine the impact these states of flying fears may have on profitability entails a critical review of the financial intricacies among commercial air carriers. The relevant hypothesis related to fear of flying is:

H1o: Airlines do not have the capacity to recoup passengers who avoid flying out of fear without increasing operating costs.

\subsection{Passengers and load factors}

Each revenue-paying passenger contributes to the overall load of an aircraft until the maximum capacity is reached. Load factor $(L F)$ information is extracted from secondary data obtained from the U.S. Department of Transportation and major airline companies' SEC Form $10-\mathrm{K}$ filings. Viewing an air carrier's $L F$ provides a basic internal and comparative measurement of effectiveness, indications if an airline is operating at full capacity, and whether an airline has either the means or needs to increase revenue. To earn profits, the seat, and its associated costs, regardless if occupied or not, must be filled with a revenue-paying passenger (Belobaba, Odoni \& Barnhart, 2015). Many airline companies critically evaluate this desired state to fill seats with paying customers as opposed to incurring a per-unit cost with no potential revenue. Figure 02 is the equation applied for determining $L F$ and

$$
L F=\sum_{i=1}^{r}\left(\frac{P * D}{A * D}\right)
$$

represents the sum of all revenue-paying passengers $(P)$ multiplied by the miles flown $(D)$, divided by the sum of available seats $(A)$ multiplied by $D$.

Load factor values are then divided by 100 to convert the raw $L F$ to a passenger seat load percentage (Jenatabadi \& Ismail, 2007). The $L F$ percentage, or ratio, provides a quick view of efficiency, capacity, and potential demand. In a macro analysis, airlines use the aggregate totals to report their overall $L F$ ratios. Although the $L F$ does not directly relate to net revenue, it provides a valuable tool to measure and monitor performance and compare performance with internal objectives and goals, or against competitors to assess the capability for increases in revenue-paying miles (RPM). Using the formula and $2014 R P M S$, Table 01 shows the aggregate computed $L F S$.

Table 1: Load factors for major U.S. domestic air carriers, 2014.

\begin{tabular}{rrrrrrr}
\hline & $\begin{array}{c}\text { Actual RPM } \\
\text { (millions of mile) }\end{array}$ & $\begin{array}{r}\text { ASM } \\
\text { (millions of miles) }\end{array}$ & $\begin{array}{r}\text { Max RPM } \\
\text { (millions of miles) }\end{array}$ & LF & $\begin{array}{r}\varepsilon \text { LF } \\
\text { (residuals) }\end{array}$ & $\sum$ LF \\
\hline 2014 & 595.34 & 704.43 & 699.00 & $85.17 \%$ & $0.66 \%$ & $85.83 \%$ \\
\hline
\end{tabular}

Figure 03 shows that for more than a decade airlines have improved LFs for domestic flights, up from 70.37 percent in 2002, to 85.17 percent through the third quarter of 2015 (Rita.dot.gov,2016a). While this information does not necessarily indicate room for improvement, it provides the stimuli to question other possibilities. During a 12 month period in 2015, the total number of revenue departures stagnated or even decreased slightly despite an increase in $L F S$ (Rita.dot.gov, 2016a). The $L F$ is only an estimated supply and demand relationship and one element of opportunity an airline considers. In a true business sense, the Operating Profit (OP) provides a better gauge of success (Jenatabadi \& Ismail, 2007).

The relevant hypothesis related to passengers and load factors is:

H2o: Recovering passengers who avoid flying has no significant influence on operating profits.

\subsection{Profitability}

To determine $O P$ requires accessing other crucial pieces of data. These data include available seat miles ( $A S M)$, cost per available seat mile (CASM), average fare prices, operating expenses, and $R P M$. The passenger seat represents a perishable per unit service production of an airline (Belobaba, Odoni \& Barnhart, 2015). The service capacity is represented by $A S M$ and is influenced by many factors ranging from the type of aircraft to maintenance availability. $A S M$ equals the length of flight in miles multiplied by the available seats on the plane. To earn profits 
requires filling seats with a revenue-paying passenger. The $R P M$ variable is the number of revenue-paying passengers occupying seats for each mile of flight. Therefore, $R P M$ equals the length of flight in miles multiplied by the number of paying passengers. The amount airlines charge customers are the airfares and cover the direct and indirect costs of each leg of a flight to include the desired margins. To understand the influence of changes in $L F, R P M, A S M$ variables Table 02 and Table 03 demonstrate the different outcomes as break-even points or required fares.

Figure 2: Load factors for domestic flights, Adapted from United States department of transportation, bureau of transportation statistics, 2016.

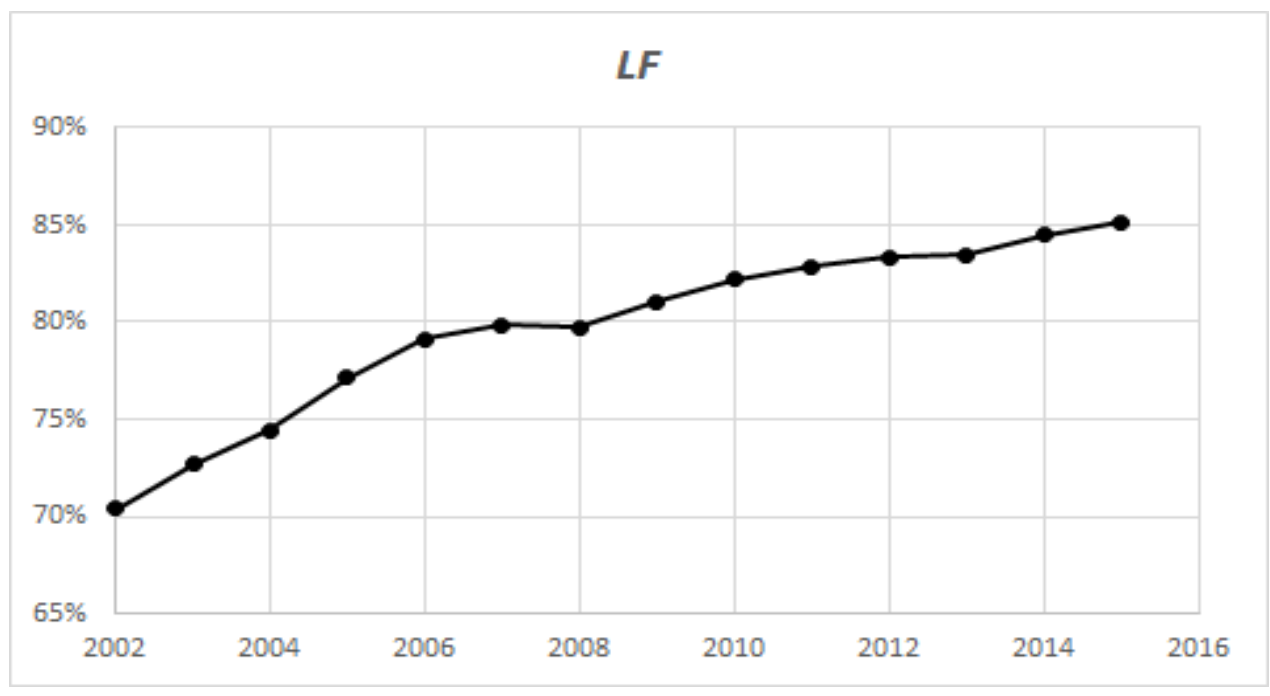

Table 2: Required fares, all things equal except total seats and LF.

\begin{tabular}{|c|c|c|c|c|c|}
\hline \multirow{4}{*}{$\begin{array}{l}\text { Flight } \\
\text { Parameters }\end{array}$} & Total seats & 266 & \multirow{4}{*}{$\begin{array}{l}\text { Flight } \\
\text { Parameters }\end{array}$} & Total seats & 247 \\
\hline & Expected $L F$ & $78.25 \%$ & & Expected $L F$ & $80.00 \%$ \\
\hline & Stage length & 4,294 & & Stage length & 4,294 \\
\hline & Block hours & 10.46 & & Block hours & 10.46 \\
\hline \multirow[t]{3}{*}{ Costs } & $\begin{array}{l}\text { Direct cost per } \\
\text { Block hour }\end{array}$ & $\$ 5,700.00$ & Costs & $\begin{array}{l}\text { Direct cost per } \\
\text { Block hour }\end{array}$ & $\$ 5,700.00$ \\
\hline & $\begin{array}{l}\text { Indirect cost per } \\
\text { block hour } \%\end{array}$ & $60.00 \%$ & & $\begin{array}{l}\text { Indirect cost per } \\
\text { block hour } \%\end{array}$ & $60.00 \%$ \\
\hline & Desired margin \% & $48.00 \%$ & & Desired margin \% & $48.00 \%$ \\
\hline \multirow[t]{5}{*}{ Financials } & ASMs (miles) & $1,142,204.00$ & Financials & ASMs (miles) & $1,060,618.00$ \\
\hline & RPMs (miles) & $893,774.63$ & & RPMs (miles) & $848,494.40$ \\
\hline & Cost per block hour & $\$ 9,120.00$ & & Cost per block hour & $\$ 9,120.00$ \\
\hline & Trip cost & $\$ 95,386.91$ & & Trip cost & $\$ 95,386.91$ \\
\hline & $\begin{array}{l}\text { Desired } \\
\text { margin }\end{array}$ & $\$ 45,785.72$ & & $\begin{array}{l}\text { Desired } \\
\text { margin }\end{array}$ & $\$ 45,785.72$ \\
\hline \multirow[t]{2}{*}{ Fares } & Required fare & $\$ 678.24$ & Fares & Required fares & $\$ 714.44$ \\
\hline & Round trip fare & $\$ 1,356.48$ & & Round trip fare & $\$ 1,428.87$ \\
\hline
\end{tabular}

Table 3: Required fares, all things equal except costs and profit margins.

\begin{tabular}{|c|c|c|c|c|c|}
\hline \multirow{4}{*}{$\begin{array}{l}\text { Flight } \\
\text { Parameters }\end{array}$} & Total seats & 247 & \multirow{4}{*}{$\begin{array}{l}\text { Flight } \\
\text { Parameters }\end{array}$} & Total seats & 247 \\
\hline & Expected $L F$ & $80.00 \%$ & & Expected $L F$ & $80.00 \%$ \\
\hline & Stage length & 4,294 & & Stage length & 4,294 \\
\hline & Block hours & 10.46 & & Block hours & 10.46 \\
\hline \multirow[t]{3}{*}{ Costs } & $\begin{array}{l}\text { Direct cost per } \\
\text { Block hour }\end{array}$ & $\$ 7,700.00$ & Costs & $\begin{array}{l}\text { Direct cost per } \\
\text { Block hour }\end{array}$ & $\$ 5,700.00$ \\
\hline & $\begin{array}{l}\text { Indirect cost per } \\
\text { block hour } \%\end{array}$ & $50.00 \%$ & & $\begin{array}{l}\text { Indirect cost per } \\
\text { block hour } \%\end{array}$ & $60.00 \%$ \\
\hline & Desired margin \% & $38.00 \%$ & & Desired margin \% & $48.00 \%$ \\
\hline \multirow[t]{4}{*}{ Financials } & ASMs (miles) & $1,142,204.00$ & Financials & ASMs (miles) & $1,060,618.00$ \\
\hline & RPMs (miles) & $848,494.40$ & & RPMs (miles) & $848,494.40$ \\
\hline & Cost per block hour & $\$ 7,050.00$ & & Cost per block hour & $\$ 9,120.00$ \\
\hline & Trip cost & $\$ 73,736.59$ & & Trip cost & $\$ 95,386.91$ \\
\hline
\end{tabular}




\begin{tabular}{|c|c|c|c|c|c|}
\hline & $\begin{array}{l}\text { Desired } \\
\text { margin }\end{array}$ & $\$ 28,019.90$ & & $\begin{array}{l}\text { Desired } \\
\text { margin }\end{array}$ & $\$ 45,785.72$ \\
\hline \multirow[t]{2}{*}{ Fares } & Required fare & $\$ 514.96$ & Fares & Required fares & $\$ 714.44$ \\
\hline & Round trip fare & $\$ 1,029.92$ & & Round trip fare & $\$ 1,428.87$ \\
\hline
\end{tabular}

The relevant hypothesis related to passengers and load factors is:

H3o: Recovering passengers who avoid flying has no significant influence on the economy.

\subsection{Demand and operating profit}

There are multiple methods to measure efficiency in an airline. Expressions used for efficiency include, but are not limited to; $L F, A S M, R P M, C A S M$, Passenger Yield $(Y / P A X)$, and operating profit (OP). Although $O P$ may provide the best indicator of success, it is important to recognize all the variables used to determine $O P$ and to achieve a greater understanding of airline efficiency and cost measures (Vasigh, Fleming \& Humphreys, 2015).

As with most businesses, the core goal of airlines is to maximize profits. Using a simple expression companies determine average $O P$ per mile by subtracting the $C A S M$ from the revenue. The sum of all expenses is expressed as operating costs. By dividing all expenses by the $A S M$, an airline can determine the CASM.

The $C A S M$ calculation applies to every level of the operation from a single flight to an aggregate sum of all flight operations. Data for the second dependent variable was extracted from the Bureau of Transportation Statistics for the year group 2014. Airline efficiency statistics were cross-referenced with major airline SEC 10-K filings to identify any anomalies. The manually calculated mean $O P$ is shown in Table 04 .

Table 4: Operating profits for U.S. domestic air carriers.

\begin{tabular}{rrrrrrrrr}
\hline $\begin{array}{r}\text { RPM (millions } \\
\text { of miles) }\end{array}$ & $\begin{array}{c}\overline{\mathbf{Y}} \\
(\$ \text { per } \\
\text { mile) }\end{array}$ & $\begin{array}{r}\sum \mathrm{Y} \\
\text { (millions } \\
\text { of } \$)\end{array}$ & $\begin{array}{r}\text { ASM } \\
\text { (millions of } \\
\text { miles) }\end{array}$ & $\begin{array}{r}\overline{\mathbf{C A S M}} \\
(\$ \text { per } \\
\text { mile) }\end{array}$ & $\begin{array}{r}\sum \text { CASM } \\
\text { (millions of } \\
\$ \text { ) }\end{array}$ & $\begin{array}{r}\text { (millions } \\
\text { of \$) }\end{array}$ \\
\hline 2014 & 595.34 & 15.09 & 89.84 & 704.43 & 12.02 & 84.69 & 5.13 \\
\hline
\end{tabular}

Note: Financial information retrieved from AMR Corporation, 2015, 2003; Delta Air Lines, Inc., 2015, 2003; Southwest Airlines Corporation, 2015, 2003; United Airlines, Inc., 2015, 2003.

\subsection{Hypotheses}

The conceptual map shown in Figure 04 is derived from a review of the literature and reveals the general relationship of supply and demand functions in the airline industry.

Figure 3: Fear of flying concept map.

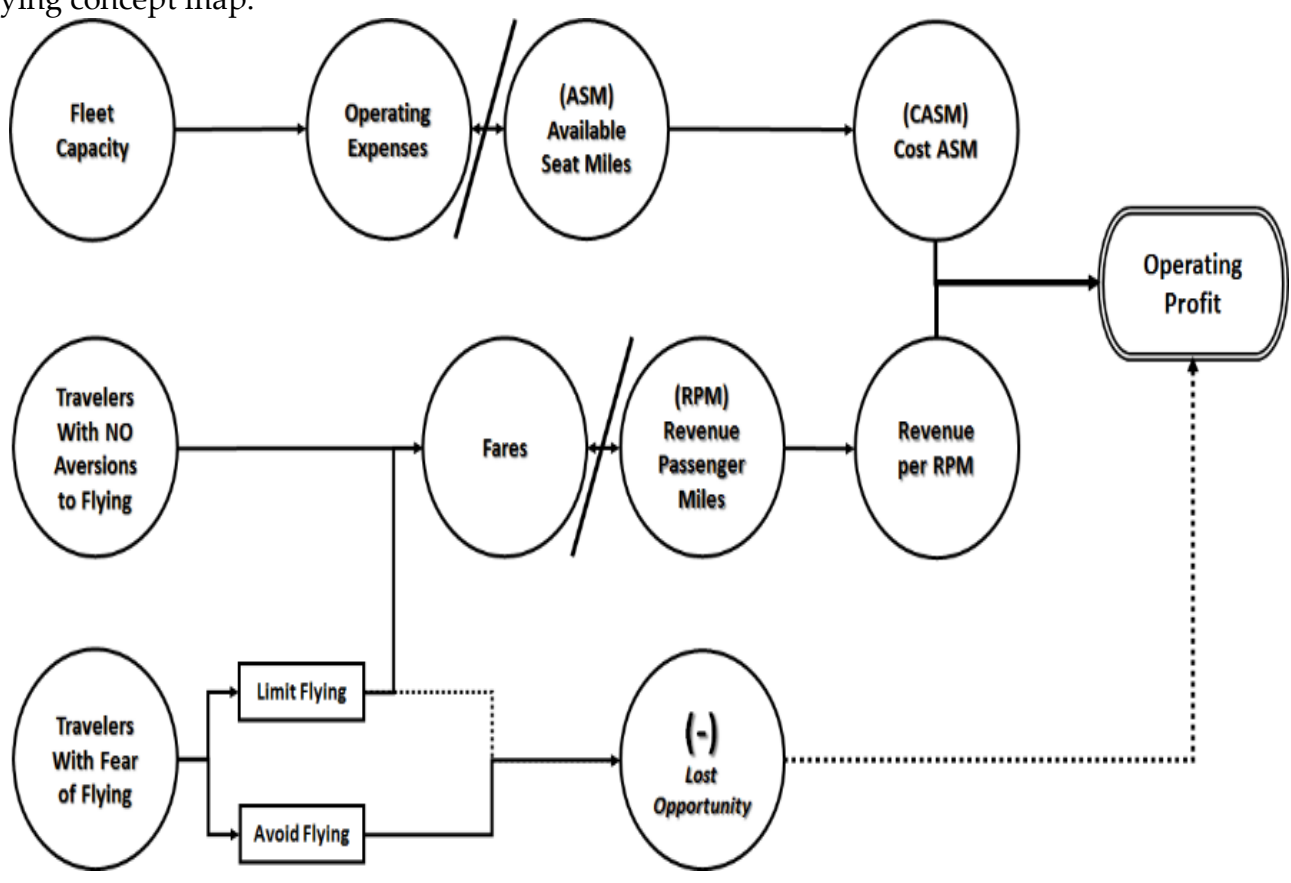




\section{Data and methodology}

The methodology for this study is an explanatory correlated research design (Creswell, 2012). The intent is to evaluate two dependent variables; fear of flying and $O P$, to show the extent in which a change in one influences the other. The process first involves a descriptive analysis to display financial information of the major domestic airlines. The second method uses a simple inferential analysis to validate the relationship between $L F$ and $O P$.

\subsection{Data}

The known data are the total population size from the 2014 U.S. Census estimates, the sample of the populations size of those who fly based on reported data, the sample of the population size of those with a fear a flying as deduced from the literature by taking a percentage of the total population, and parameters of airline profits from the U.S. Department of Transportation and SEC Form 10-K filings.

Fear of flying descriptive statistics represent percentages of travelers who fear or avoid flying from the literature (Dean \& Whitaker, 1982; Fleischer, Tchetchik \& Toledo, 2012). These percentages were compared with the latest data in the Omnibus Household Survey (Rita.dot.gov, 2016b). The methodology of this research requires that the population sample is limited to one group (Creswell, 2012). Although subpopulations were established based on diagnosed and undiagnosed fears of flying, these subpopulations were combined and treated as a single size. The extent at which either of these subpopulations elects not to fly is a moderating variable, which is graphically depicted in the concept map in Figure 04.

\subsection{Populations and samples}

Major air carriers account for 595.34 million of the total 66.82 million U.S. domestic passengers in 2014, or 89.92 percent, a more than ample size (Rita.dot.gov, 2016a). According to the U. S. Census Bureau (2016), the 2014 U.S. population was 321.42 million people. Although dated, available research shows 2.5 percent of the population are clinically diagnosed aviophobiacs who do not fly, and 17 percent to 20 percent of the population expressed a fear of flying (Fredrikson, Annas, Fisher \& Wilk, 1996; Dean \& Whitaker, 1982; Agras, Sylvester \& Oliveau, 1969). Department of Transportation data also reports only 39.85 percent of Americans have flown in the last 12 months, and 18 percent of Americans have never flown. The independent research findings are also corroborated by The Omnibus Household Surveys (Rita.dot.gov, 2016b).

Using the lower spectrum of estimates, we can determine 8.03 million Americans (2.5 percent of the current total population) refuse to fly, and an additional 46.61 (14.5 percent of the current total population) million Americans have a fear of flying and are likely to limit their exposure to the perceived psychophysiological risks. These population sizes are somewhat lower than those generalized from epidemiological studies by Oakes and Bor (2010). The unknown variable is the extent at which those expressing a fear of truly avoid or limit flying. Although this study does not precisely determine a value, it ascertains a range, which is displayed and evaluated in quartile increments. The population totals of those with various degrees of airline travel avoidance out of fear are depicted in Table 05.

Table 5: Sample populations.

\begin{tabular}{llr}
\hline Symbol & Description & $\begin{array}{r}\text { Population size } \\
\text { (In millions) }\end{array}$ \\
\hline$D F$ & Diagnosed Fear with 100 percent air travel avoidance & 8.03 \\
$E F_{1}$ & Expressed Fear with the supposition of 100 percent air travel avoidance & 46.61 \\
$E F_{2}$ & Expressed Fear with the supposition of 75 percent air travel avoidance & 34.95 \\
$E F_{3}$ & Expressed Fear with the supposition of 50 percent air travel avoidance & 23.30 \\
$E F_{4}$ & Expressed Fear with the supposition of 20 percent air travel avoidance & 11.65 \\
\hline
\end{tabular}

Note: DF represents the number of potential passengers who do not fly in response to a diagnosed fear. The EF values represent the numbers, which have an undiagnosed fear, sectioned by quartiles ranging from a total aversion to flying to a 25 percent aversion to flying.

\section{Results and discussion}

\subsection{Descriptive analysis}

From 2014, the known actual mean $\overline{L F}$ is 85.17 percent, actual $R P M s$ are 595.34 million miles, the maximum possible RPMs are 699.00 million miles, and the $A S M S$ are 704.43 million miles. By subtracting the actual $L F$ from a $L F$ based off the maximum $R P M S$ a residual $(\mathcal{E})$, or unaccounted for, portion of the $L F S(E L F)$ is identified. This residual can be attributed to a seat that is either not occupied because it is not functional, or is occupied but no 
revenue is received. The total $L F$ is determined by adding the residual to the actual $L F$ to obtain a true or total $L F$ $\left(\sum L F\right)$ as shown in Table 06.

Table 6: Mean, residual, and total load factors for 2014.

\begin{tabular}{llccc}
\hline Variable & $\begin{array}{l}\text { RPM } \\
\text { (millions of miles) }\end{array}$ & $\overline{\mathbf{L F}}$ & $\boldsymbol{\varepsilon} \overline{\boldsymbol{L F}}$ & $\sum L F$ \\
\hline 2014 & 595.34 & $85.17 \%$ & $1.81 \%$ & $86.98 \%$ \\
\hline
\end{tabular}

By adding the lost opportunity from fear of flying $L F s, R P M s$, mean $\overline{L F}, \varepsilon L F$ the $\sum L F$ can easily be recalculated. These new $L F$ s are depicted in Table 07.

Table 7: LFs with adjusted RPMs.

\begin{tabular}{lrrrr}
\hline Variable & $\begin{array}{r}\text { RPM } \\
\text { (millions of miles) }\end{array}$ & $\overline{\boldsymbol{L F}}$ & $\boldsymbol{\varepsilon} \overline{\boldsymbol{L F}}$ & $\sum L F$ \\
\hline 2014 & 595.34 & $85.17 \%$ & $1.81 \%$ & $86.98 \%$ \\
$D F$ & 603.37 & $86.32 \%$ & $1.81 \%$ & $88.13 \%$ \\
$E F_{1}$ & 649.98 & $92.99 \%$ & $1.81 \%$ & $94.80 \%$ \\
$E F_{2}$ & $638, .33$ & $91.32 \%$ & $1.81 \%$ & $93.13 \%$ \\
$E F_{3}$ & 626.69 & $89.65 \%$ & $1.81 \%$ & $91.46 \%$ \\
$E F_{4}$ & 615.02 & $87.99 \%$ & $1.81 \%$ & $89.80 \%$ \\
\hline
\end{tabular}

The descriptive statistics are not only crucial for the financial calculations but reveal that recovering lost opportunities will increase $R P M S$ and the total $L F s$. If the $\sum L F$ reaches or exceeds 100 percent, then the only way to retrieve a missed opportunity would be to generate more $A S M S$.

To increase $A S M s$ requires more flights or larger capacity aircraft and would change the CASM. If $\sum L F$ does not reach or exceed 100 percent, an opportunity can be recovered without incurring significant costs or changes to airline flight operations.

The mean yield per $R P M$ represents the average spent per passenger, per mile, in cents. This rate is static using 2014 averages of major U.S. domestic airlines. The mean CASM is the average cost per mile, in cents, U.S. domestic airlines pay per passenger. This rate is also static using the aggregate mean of 2014 averages for major U.S. domestic airlines.

Potential travelers with either a diagnosed or an expressed fear of flying represent a yet to be proven potential lost opportunity. By changing the RPMvalues to include possible revenue-paying passengers who either avoid or minimize air travel, the $O P S$ can be calculated. To improve the accuracy of $O P$ values, a further adjustment is required using air travel rates and recurring travel rates from the Omnibus Household Survey. Even if those with a fear of flying did fly, there are standard occurrence rates and frequencies, in which flying would be a normal expectation. Therefore, a more realistic representation, using the 39.5 percent recurring flying rate, is shown Table 08.

Table 8: Unadjusted operating profits factoring in fear of flying passengers.

\begin{tabular}{lrrrrrrr}
\multicolumn{2}{c}{ Table 8: Unadjusted operating profits factoring in fear of flying passengers. } \\
\hline $\begin{array}{r}\text { RPM } \\
\text { (Millions } \\
\text { of miles) }\end{array}$ & $\begin{array}{r}\text { Avg Yield } \\
(\$ \text { per } \\
\text { mile) }\end{array}$ & $\begin{array}{r}\text { RPM*Yield } \\
\text { (Millions of } \$)\end{array}$ & $\begin{array}{r}\text { ASM } \\
\text { (Millions } \\
\text { of miles) }\end{array}$ & $\begin{array}{r}\text { AVG CASM }(\$ \\
\text { per mile) }\end{array}$ & $\begin{array}{r}\text { ASM*CASM } \\
\text { (Millions of } \\
\$ \text { ) }\end{array}$ & $\begin{array}{r}\text { OP } \\
\text { (RPM*Yield) } \\
\text { Less } \\
\text { (ASM*CASM) }\end{array}$ \\
\hline 2014 & 595.34 & 15.09 & $\$ 89.82$ & 704.43 & 12.02 & $\$ 84.69$ & $\$ 5.13$ \\
$\mathrm{DF}$ & 603.37 & 15.09 & $\$ 91.03$ & 704.43 & 12.02 & $\$ 84.69$ & $\$ 6.34$ \\
$\mathrm{EF}_{1}$ & 649.98 & 15.09 & $\$ 98.06$ & 704.43 & 12.02 & $\$ 84.69$ & $\$ 13.37$ \\
$\mathrm{EF}_{2}$ & 638.33 & 15.09 & $\$ 96.31$ & 704.43 & 12.02 & $\$ 84.69$ & $\$ 11.62$ \\
$\mathrm{EF}_{3}$ & 626.69 & 15.09 & $\$ 94.55$ & 704.43 & 12.02 & $\$ 84.69$ & $\$ 9.86$ \\
$\mathrm{EF}_{4}$ & 615.03 & 15.09 & $\$ 92.79$ & 704.43 & 12.02 & $\$ 84.69$ & $\$ 8.10$ \\
\hline
\end{tabular}

4.2 Inferential analysis

A quick view of the descriptive statics shows a positive correlation between increasing $R P M S$ by recouping the lost opportunity from travelers who fear flying and $O P$ given the $C A S M$ does not change. A Pearson correlation analysis reveals a near perfect correlation (.99) between the $x$ and $y$ variables with 4 degrees of freedom, in which the $r$ critical value need only, reach or exceed 0.8114 to show a significant correlation.

\section{$4.3 \quad$ Findings}


The first hypothesis asserted U.S. domestic air carriers do not have the capacity to meet an increased demand attributed to the current LFS. A more complex hypothesis emerged from the first whereby recovery of a lost opportunity from fearful flyers would result in no increase to $O P$. From prior research, and with some degree of conjecture, the final hypothesis asserts that securing addition demand by recouping lost opportunity from fearful flyers has no positive effect on the economy. From the analysis, all three hypotheses are rejected as shown in Table 09.

Table 9: Results of hypotheses tests.

\begin{tabular}{|c|c|c|}
\hline Hypothesis & Decision & Results \\
\hline $\begin{array}{l}\text { H1o: Airlines do not have the } \\
\text { capacity to recoup passengers } \\
\text { who avoid flying out of fear } \\
\text { without increasing operating } \\
\text { costs. }\end{array}$ & Rejected & $\begin{array}{l}\text { - Recovering all passengers exhibiting a fear or aversion to } \\
\text { flying and adding, the residual э } \overline{L F} \text { results in an aggregate } \\
\text { total } \sum L F \text { of } 94.8 \% \text {. } \\
\text { - With the current } L F<100 \% \text { these potential passengers can } \\
\text { be added without increasing flights, fleet compositions, or } \\
\text { changing the cost per mile, per seat (CASM) }\end{array}$ \\
\hline $\begin{array}{l}\text { H2o: Recovering passengers } \\
\text { who avoid flying have no } \\
\text { significant influence on } \\
\text { operating profits. }\end{array}$ & Rejected & $\begin{array}{l}\text { - The } L F \text { is not exceeded. Thus the average } C A S M \text { is static } \\
\text { - No changes in } C A S M \text { results in no changes operating costs. } \\
\text { - With a static } C A S M \text { and no increase in cost, every additional } \\
R P M \text { increases } O P\end{array}$ \\
\hline $\begin{array}{l}\text { H3o: Recovering passengers } \\
\text { who avoid flying have no } \\
\text { significant influence on the } \\
\text { economy... }\end{array}$ & Rejected & $\begin{array}{l}\text { - Increasing the } O P \text { generates additional revenue } \\
\text { - Based on Iatrou's (2014) research the economic impact is } 3.25 \\
\text { times the value of each additional dollar earned } \\
\text { - Economic benefits are supported by Belobaba, Odini, and } \\
\text { Barnhart (2015) and the U.S. Department of Transportation } \\
\text { (2015) }\end{array}$ \\
\hline
\end{tabular}

An effort to recoup a lost opportunity from travelers too afraid to travel by air can be supported by major U.S. domestic airlines without any significant operational changes or operating costs. The current mean $L F$ for airlines is 85.17 percent. Even if 100 percent of travelers with either a diagnosed or an undiagnosed fear were recouped, the $L F$ would only need to increase by 7.82 percent to total, including residuals, 94.8 percent.

There are potential gains to U.S. domestic airline companies if potential passengers who avoid flying can be recouped. We determined the financial loss to major U.S. airlines is an economic impact is between \$19.64 million and \$29.45 million a year as shown in Table 10. Although this further support the rejection of the last hypothesis and appears to represent a significant amount, when comparing percentages of increases in relation to the overall economy it may arguably be small.

Table 10: Economic impact in indirect revenue from the recovery of lost opportunity.

\begin{tabular}{|c|c|c|c|}
\hline & & $\begin{array}{r}\text { Revenue } \\
\text { (millions of \$) }\end{array}$ & $\begin{array}{r}\text { Indirect Revenue } \\
(\text { millions of } \$)\end{array}$ \\
\hline 2014 & Baseline & 5.13 & 17.95 \\
\hline$D F$ & Only Diagnosed Fear & 5.61 & 19.64 \\
\hline$E F_{1}$ & Diagnosed \& Undiagnosed with $100 \%$ flight avoidance & 8.41 & 29.45 \\
\hline$E F_{2}$ & Diagnosed \& Undiagnosed with $75 \%$ flight avoidance & 7.71 & 27.00 \\
\hline$E F_{3}$ & Diagnosed \& Undiagnosed with $50 \%$ flight avoidance & 7.01 & 24.55 \\
\hline$E F_{4}$ & Diagnosed \& Undiagnosed with 25\% flight avoidance & 6.31 & 22.09 \\
\hline
\end{tabular}

\subsection{Policy implications}

These findings should be interpreted with caution. The analysis and findings do not consider potential monetary or psychological costs of recovering this lost opportunity to include planing or behavioral modification expenses and the impacts it may have on other passengers. Available data of flying phobias is dated and may not capture the current perceptions of today's travelers based on improved safety, increased security, aviation technological advances, real-time social media, terrorism trends, and recent catastrophic failures (Aamir \& Vargas, 2012; Barnett, Menighetti \& Prete, 1992; Becker, 1992; Borenstein \& Zimmerman, 1988). The source of financial data is derived from non-GAAP cost accounting methods and uses only mean data from major domestic U.S. air carriers. There is little evidence of what an optimum $L F$ would be. Conditions may exist where a higher $L F$ is undesirable, as well as the fact an increased $L F$ may change CASMS even if capacity is not exceeded (Belobaba, 1987; Yang, Raeside \& Smyth, 2005; Collins \& Thomas, 2013). 


\section{Conclusion}

The research does indicate a potential lost opportunity, but by itself cannot support the need to recoup it. Further research could examine the fear of flying population in greater detail. This can be accomplished by determining a more reliable subpopulation size that includes avoidance frequencies of those who simply express fear.

Future research on the influence of significant events, particularly security and threats on fear of flying could provide valuable marketing and analyses for the industry. From a financial perspective, additional research to examine causal effects of adding more seats, improving customer service, and cost reduction methods could either support or dissuade recovering the lost opportunity. Prospective qualitative research methods could monitor and report employee attitudes towards consumers with an aversion to flying, as well as evaluating the effectiveness of programs designed to relieve or overcome fear. Qualitative and longitudinal studies could follow air travelers with expressed fears evaluating not only their aversions to flying.

Although airlines can certainly artificially inflate $L F S$ by limiting demand, the result is no real growth. Enticing passengers who have a fear of flying can increase. Recapturing this lost opportunity could increase $L F S$, $R P M S$, and OPS provided there be no substantial changes in CASMS. Although there is evidence of financial gains for airlines and a positive economic impact from recovering travelers lost because of a fear of flying, the significance is not as high as reported in some literature. Ultimately, only an airline can decide if the cost of capturing the lost opportunity is financially viable. However, the traditional practice airlines follow in avoiding discussions centered on factors that may negatively influence fear of flying should be further studied. Fear of flying is a widely ignored yet common condition extending back to the initiation of commercial flights (Oakes \& Bor, 2010). Domestic passengers who fear flying not only represent a lost opportunity factored out of the financial equations by airlines in an unstable and hyper-competitive market, but also represents personal consequences better defined for future research and policy development.

\section{References}

Aamir, M., \& Vargas, V. (2012). Model of driver of fear-induced consumer avoidance behaviors post-incident. In System Dynamics Conference (pp. 1-23). Albuquerque, NM: Sandia National Laboratories.

Agras, S., Sylvester, D., \& Oliveau, D. (1969). The epidemiology of common fears and phobias. Compr Psychiatr, 10(2):151-156. https://doi.org/10.1016/0010-440X(69)90022-4

American Psychiatric Association. (2000). Diagnostic and statistical manual of mental disorders (4th ed., text rev.). doi:10.1176/appi.books.9780890423349

AMR Corporation. (2003). Form 10-K 2003. Retrieved from SEC EDGAR website http://www.sec.gov/edgar.shtml

AMR Corporation. (2015). Form 10-3Q 2015. Retrieved from SEC EDGAR website http://www.sec.gov/edgar.shtml

Armantier, O., \& Richard, 0. (2008). Domestic airline alliances and consumer welfare. The RAND Journal of Economics, 39(3), 874-904. Retrieved from http://uiwtx.idm.oclc.org/login?url= http://search.proquest.com.uiwtx.idm.oclc.org/docview/236523098?accountid=7139, https://doi.org/10.1111/j.1756-2171.2008.00042.x

Barnett, A., Menighetti, J., \& Prete, M. (1992). The market response to the Sioux City DC-10 crash. Risk Analysis, 12(1), 45-52. https://doi.org/10.1111/j.1539-6924.1992.tb01306.x

Becker, T. (1992). Passenger perceptions of airline safety: Marketing safety records. Flight Safety Digest, 1-6.

Belobaba, P. (1987). Survey Paper-Airline yield management an overview of seat inventory control. Transportation Science, 21(2), 63-73. https://doi.org/10.1287/trsc.21.2.63

Belobaba, P., Odoni, A., \& Barnhart, C. (2015). The Global Airline Industry (2nd ed.). West Sussex, United Kingdom: John Wiley \& Sons.

Borenstein, S., \& Zimmerman, M. (1988). Market incentives for safe commercial airline operation. The American Economic Review, 913-935. Retrieved from http://www.jstor.org/stable/1807157

Census.gov, (2016). 2014 National Population Projections - People and Households - U.S. Census Bureau. Retrieved 18 January 2016, from https://www.census.gov/population/projections/data/national/ 2014.html

Collins, A., \& Thomas, L. (2013). Learning competitive dynamic airline pricing under different customer models. Journal of Revenue and Pricing Management, 12(5), 416-430. doi: http://dx.doi.org.uiwtx.idm.oclc.org/10.1057/rpm.2013.10

Crangle, M. (2010). Conquer your fear of flying. Dublin, Ireland: Gill \& Macmillan.

Creswell, J. (2012). Educational research: Planning, conducting, and evaluating quantitive and qualitative research (4th ed.). Boston, MA: Pearson Education, Inc.

Dean. R. D., \& Whitaker, K. M. (1982). Fear of flying: impact on the US air travel industry. Journal of Travel Research, 51(9). 653-66. https://doi.org/10.1177/004728758202100104 
Delta Air Lines, Inc. (2003). Form 10-K 2003. Retrieved from SEC EDGAR website http://www.sec.gov/edgar.shtml

Delta Air Lines, Inc. (2015). Form 10-3Q 2015. Retrieved from SEC EDGAR website http://www.sec.gov/edgar.shtml

Evangelisti, L. (2008). Mai più paura di volare [No more fear of flying]. Milan: Kowalski.

Faraci, P., Triscari, M., D'Angelo, V., \& Ursof, V. (2011). Fear of flying assessment: A contribution to the Italian validation of two self-report measures. Review of Psychology, 18(2), 91 -100.

Fleischer, A., Tchetchik, A., \& Toledo, T. (2012). The impact of fear of flying on travelers' flight choice: Choice model with latent variables. Journal of Travel Research, 51(5), 653-663. Retrieved from http://toledo.net.technion.ac.il/files/2016/02/JTR_flightFear_12.pdf, https://doi.org/10.1177/0047287512437856

Fredrikson, M., Annas P., Fischer H., \& Wilk, G. (1996). Gender and age differences in the prevalence of specific fears and phobias. Behaviour Research and Therapy, 34(1), 33-39. doi:10.1016/0005-7967(95)00048-3

Hansman, R., \& Ishutkina, M. (2009). Analysis of the interaction between air transportation and economic activity: A worldwide perspective. Dspace.mit.edu. Retrieved 27 January 2016, from http://dspace.mit.edu/handle/1721.1/44957

Hernandez, M., \& Wiggins, S. (2014). Nonlinear pricing strategies and competitive conditions in the airline industry. Economic Inquiry, 52(2), 539-561. doi:10.1111/ecin.12045

International Airline Transport Association. (2015). Economic performance of the airline industry. Retrieved from https://www.iata.org/whatwedo/Documents/economics/IATA-Economic-Performance-of-the-Industrymid-year-2015-report.pdf

Iatrou, K. (2014). 100 years of commercial aviation. Montréal, Canada: Hermes Transport Club Publishing.

Jenatabadi, H. S., \& Ismail, N. (2007). The determination of load factors in the airline industry. International Review of Business Research Papers, 3(4), 125-133. Retrieved from http://www.bath.ac.uk/ejournals/jtep/pdf/Volume_V111_No_3_260-273.pdf

Kappler, M., \& Sachs, A. (2013). Business cycle synchronization and economic integration. New York, NY: Springer. https://doi.org/10.1007/978-3-7908-2855-9

Laker, M. (2012). Specific phobia: Flight. The Journal for Neurocognitive Research: Activitas Nervosa Superior, 54(3): 108-117.

Nousi, A., Van Gerwen, L., \& Spinhoven, P. (2008). The flight anxiety situations questionnaire and the flight anxiety modality questionnaire: Norms for people with fear of flying. Travel Medicine and Infectious Disease, 6, 305310. doi:10.1016/j.tmaid.2008.06.001

Oakes, M., \& Bor, R. (2010). The psychology of fear of flying (part I): A critical evaluation of current perspectives on the nature, prevalence and etiology of fear of flying. The Journal of Travel Medicine and Infectious Disease, 8, 327-338. doi:10.1016/j.tmaid.2010.10.001

Rita.dot.gov. (2016a). Bureau of Transportation Statistics. Retrieved 1 February 2016, from http://www.rita.dot.gov/bts/

Rita.dot.gov. (2016b). Omnibus Household Survey: Bureau of Transportation Statistics. Retrieved 2 February 2016, from https://www.rita.dot.gov/bts/sites/rita.dot.gov.bts/files/subject_areas/omnibus_surveys/ household_survey/index.html

Southwest Airlines Corporation. (2003). Form 10-K 2003. Retrieved from SEC EDGAR website http://www.sec.gov/edgar .shtml

Southwest Airlines Corporation. (2016). Form 10-K 2015. Retrieved from SEC EDGAR website http://www.sec.gov/edgar.shtml

United Airlines, Inc. (2003). Form 10-K 2010. Retrieved from SEC EDGAR website http://www.sec.gov/edgar.shtml

United Airlines, Inc. (2015). Form 10-3Q 2015. Retrieved from SEC EDGAR website http://www.sec.gov/edgar.shtml

U.S. Department of Transportation. (2015). The economic impact of civil aviation on the US economy (pp. 1-17). Federal Aviation Administration. Retrieved from https://www.faa.gov/air_traffic/publications/media/ 2015-economic-impact-report.pdf

Van Gerwen, L. J., Diekstra, R. F. W., Arondeus, J. M., \& Wolfger, R. (2004). Fear of flying treatment programs for passengers: an international update. Travel Medicine and Infectious Disease, 2, 27-35. doi:10.1016/j.tmaid.2004.01.002

Vasigh, B., Fleming K., \& Humphreys, B. (2015). Foundations of airline finance (2nd ed.). New York, NY: Routledge. Vasigh, B., Fleming, K., \& Taeker, T. (2008). Introduction to air transport economics: from theory to applications. Burlington, VT: Ashgate.

Yang, D., Raeside, R., \& Smyth, A. (2005). The use of load factors to segment airline operators. Journal of Revenue and Pricing, 4(2), 195-203. 